\title{
Ex-Jesuit Librarian-Scholars Adam František Kollár and György Pray: Baroque Tradition, National Identity, and the Enlightenment among Jesuits in the Eastern Habsburg Lands
}

\author{
Paul Shore \\ University of Regina \\ shorp@brandonu.ca
}

\begin{abstract}
The former Jesuits Adam František Kollár and György Pray each devoted much of their careers to work in libraries; thereby contributing to the literary and scholarly culture of the eastern Habsburg lands during the second half of the eighteenth century. Kollár, who left the Jesuits early in his career, authored works defending the rights of the Hungarian crown, and chronicled the history of the Rusyn people, ultimately achieved an international reputation as a scholar, coining the term ethnologia. Pray is remembered for his discovery of the oldest written example of the Hungarian language, his extensive historical publications, and for his role, following the papal suppression of 1773 , as "Historiographus Hungariae" (Hungary's hagiographer). The impact of these scholarly efforts by these former Jesuits was a rich and enduring foundation upon which later Hungarian historiography and library science would be based.
\end{abstract}

\section{Keywords}

Enlightenment - Jesuit - Adam František Kollár - György (Georgius) Pray

The decades both immediately preceding and following the suppression of the Society of Jesus in 1773 were a time of intellectual ferment in the Habsburg lands east of the Leitha. While the stimulus for much of this activity came from the Imperial court, where first Maria Theresa (r.1740-80) and then her son

(C) PAUL SHORE, $2019 \mid$ DOI:10.1163/22141332-00603004

This is an open access article distributed under the terms of the prevailing CC-BY-NC license at the time of publication. 
Joseph II (r.1765-9o) instituted reforms and innovations, other forces played an important role in shaping the ideas of the day. ${ }^{1}$ Expanding towns such as Pest were home to those who eagerly read books and newspapers, as well as to printers, who increased their numbers from seventeen to fifty-one in the years between 1760 and $1790 .{ }^{2}$ In this environment, a growing awareness of ethnic identity among the many groups living in the region, and an engagement by educators and scholars - many of them Jesuits and ex-Jesuits—in questions of preservation, collation, and interpretation of historical records, proved decisive. The suppression of the Society of Jesus itself forced changes in the collection and organization of books and other documents, while simultaneously compelling many former Jesuits to change location and occupation. In Habsburg Hungary especially, the entire literary landscape was in a state of transformation and tension heightened by both Josephinian reforms and the reactions against them. The essay will briefly review the careers of two men from Habsburg Hungary, both trained as Jesuits, whose lives spanned the period when baroque and Enlightenment values shaped book production and collection, and for whom the atmosphere of reform and the suppression of the Society of Jesus created challenges, opportunities, and a profoundly changed landscape in which to pursue their work. In describing important aspects of the pre-1773 Society as "baroque" we will highlight the following points. First, the baroque piety of the old Society, which endured in any quarters, including Eastern Europe, until 1773, had dramatic aspects, and not merely it the visual arts. Homiletics and polemics retained a heightened emotional intensity. ${ }^{3}$ The "baroque" as opposed to the "encyclopedic" approach to data collection sought out the unique, if not the bizarre, which, in the case of the Jesuits, led them to remain desirous of linking together widely disparate pieces of data. Finally, the baroque Society cultivated a universalist position quite distinct

1 R. J. W. [Robert John Weston] Evans, Austria, Hungary, and the Habsburgs: Central Europe c. 1683-1867 (Oxford: Oxford University Press, 2006), 44-49.

2 Ana Maria Roman-Negoi, "Politica editorială a Tipografiei Universității din Buda la începutul secolului al XIX-lea," Libraria: Studii și cercetări bibliologie 11 (2012): 56-62, here 57n4, http:// www.e-antropolog.ro/2011/11/politica-editoriala-a-tipografiei-universitatii-din-buda-lainceputul-secolului-al-xix-lea/ (accessed January 25, 2019).

3 Hughes Oliphant Old characterizes the baroque Jesuit sermon as "long, erudite, and dramatic." The first two descriptors are especially important: the cumulative effect of a long sermon or dramatic work, coupled with references that appealed to the learned, and flourishes that shocked the masses, stands in contrast to, for example, the gentle Romantic moralizing found in Pestalozzi's works. Hughes Oliphant Old, The Reading and Preaching of the Scriptures in the Worship of the Christian Church, vol. 4: The Age of the Reformation (Grand Rapids: Eerdmans, 2002), 149 . 
from what the two scholars considered here pursued inasmuch as each was dealing with the origins of individual populations and not with connecting these populations with biblical narratives such as the Tower of Babel. Adam František Kollár (1718-83) and György Pray (1723-1801), whose interests and accomplishments bear some common features, are sometimes referred to as key figures in a "Jesuit school" of Hungarian history. Yet these two are better understood as individual examples of often isolated former Jesuits compelled to negotiate not merely their own careers and livelihoods, but also their scholarly undertakings in an environment utterly unlike the one in which they had been trained. The international culture of the Enlightenment could potentially provide audiences and sponsors for the labors of historians and librarians. However, these supports differed fundamentally from the arrangements baroque Jesuits had sought and often gained from monarchs committed to the Catholic Church, and from a strong, centralized Society. We shall therefore argue that the conservative nature of their Jesuit formation notwithstanding, Kollár and Pray used the skills acquired in that formation to engage issues of concern to Enlightenment thinkers, among them the definition of human populations in accordance with history and language, the attempt impartially to study documentary evidence of historical events, and the emphasis on the function of schooling in a society whose goals were not exclusively religious.

Hungary's circumstances were ripe for a flowering of historical scholarship. After a century and a half of Ottoman domination, Hungary underwent a bloody liberation by Habsburg and allied forces at the end of the seventeenth century. Additional turmoil had already taken place during the 1677 rebellion of Imre Thököly (1657-1705) (who aided the Ottomans during the 1683 siege of Vienna). The War of Independence led by Francis II Rákóczi (1703-11) produced profound disruption and destruction, especially to educational institutions. But by mid-century, Hungary and the Jesuit educational network within it had largely recovered. In this milieu the Jesuit educational network produced many important intellectuals, several of whom lived into the era following the Society's suppression. It is here that the life stories of Kollár and Pray begin.

Adam František Kollár de Keresztén, the "Slovak Socrates," is the better known of the two men considered here. Born into the minor nobility of Terchová, Kollár grew up in Banská Bystrica (German: Neusohl; Hungarian: Besztercebánya), where he attended a Jesuit school. Kollár continued his education in Trnava and Vienna, completing his training in theology in 1748 , at which point he left 
the Society of Jesus which he had joined in $1737 .{ }^{4}$ Kollár soon embarked on a career at the Imperial Royal Library in Vienna which continued until his death. ${ }^{5}$ Working in an environment where he had access to accounts of historical researches abroad, Kollár was influenced by the pioneering archival work of Jean Mabillon (1632-1707) and Ludovico Muratori (1672-1750). In 1769, Kollár organized a new library based on the model of Peter Lambeck (Lambecius) (1628-80). ${ }^{6}$ Among Kollár's many achievements during these years was his coining of the term ethnologia (often misattributed to Alexandre-César Chavannes) in 1783. In true Enlightenment spirit, Kollár defined ethnologia as "the science of nations and peoples [...] [an inquiry into] the origins, customs, languages and institutions of various nations, and finally into their fatherlands and ancient seats [...]."7 Writing in Latin, Kollár distinguished between a "nation" (gens) and a "people" (populus): the former grouping shares common ancestry while the latter has a historical or geographical connection. The Roman gentes had also shared ancestral religious rites, a fact that Kollár, trained in the Ratio studiorum curricular model that had included authors such as Livy (59 ВCE-17 CE), would have known. ${ }^{8}$ Kollár was aware of the diverse ethnic makeup of the eastern Habsburg lands which then included Roma, Serbs, Jews, Armenians, and a scattering of mostly clandestine Muslims. Had he lived longer, Kollár's own views on the significance of religious rites to an application of ethnologia to research on these groups might have become clearer. However, he died the same year that his definition of this term appeared. Other influences on Kollár's articulation of ethnologia have been identified, among them scholars at the University of Göttingen, particularly the Orientalist August Ludwig von Schlözer (1735-1809). However, the above discussion of ethnologia

4 According to one account, Kollár left the Society because of his father's straitened financial circumstances. Eduard Duller, Maria Teresa ed i suoi tempi, trans. Felice Griffini (Milan: Carlo Rettig, 1845), 503 .

5 In 1774, Kollár became director of the library, as well as assuming other responsibilities, for the princely sum of four thousand florins. Ignaz Franz von Mosel, Geschichte der Kaiserl. königl. Hofbibliothek zu Wien (Vienna: F. Beck'sche Universitäts-Buchhandlung, 1835), 163.

6 Bruckner János, “A jozefinista kultúrpolitika és az Egyetemi Könyvtár (1780-1784)," Magyar Könyvszemle 72, no. 2 (1956): 112-37, here 120.

7 Adam František Kollár, Historiae iurisque publici regni Hungariae amoenitates, 2 vols. (Vienna: Typis a Bavmeisterianis, 1783), 1:80: "notitia gentium populorumque, sive est id doctorum hominum studium, quo in variarum gentium origines, idiomata, mores, atque instituta, ac denique patriam vetustasque sedes eo consilio inquirunt, ut de gentibus populisque sui aevi rectius judicium ferre possint."

8 Gens and populus for example appear in Livy's Ab urbe condita [From the founding of the city (Rome)], 22.54. 
articulated by Kollár was the first time the term had been clearly defined. ${ }^{9}$ Kollár, a protégé of, and successor to Gerhard van Swieten (1700-72) as director of the Imperial library, was thus both an heir to, and a rejecter of, the baroque Society's approaches to what were later called the social sciences. While drawing upon terminology and categories that would have made sense to Jesuits of a century earlier, Kollár betrays no interest in constructing a model for presenting a unified or universal origin of peoples and languages. Kollár's approach to data collection also suggests an Enlightenment rejection of universalist models and theologically-driven theories of history still popular in his day. Kollár additionally played a key role in the drafting of the Ratio educationis (1777), a program for educational reform in Hungary. The identity of the first part of its title with the Jesuit Ratio studiorum is unlikely to be a coincidence, and the two documents shared an emphasis on standardized teaching methods, curricula, and textbooks. However, the Ratio educationis was based on very different principles, focusing not on the development of classical eloquentia to be displayed by men in the public sphere, but instead upon a Habsburg interpretation of the Enlightenment ideals of "fide erga Principem, Patriæ ac civium caritatem" (loyalty to the ruler and the homeland, and love of fellow citizens). ${ }^{10}$ These virtues raised the state and its citizens to the highest level of honor: civic virtue, which has been described as an expression of a post-Christian polity, is promoted by the state, which is in turn one of its chief beneficiaries. ${ }^{11}$ Citizens demonstrating these virtues are not motivated by fear or hope of consequences in the next life. The distance from the values of the Ratio studiorum is striking, and the compatibility of such a benevolent state with the claims Kollár made for the authority of the Habsburgs is clear. Notably, these ideas were to be fostered in schools where instruction for both boys and girls might be in the vernacular. The influence of Kollár, who has been called a "confidant" of the empress, ${ }^{12}$ extended through his students. Jakab Ferdinánd Miller (1749-1823),

Kollár drew upon von Schlözer's German term ethnographisch which had appeared a few years earlier but had not been defined rigorously insofar as von Schlözer had generalized his concept of what Kollár called "ethnologia" by encompassing within it both peoples (populi) and nations (gentes). Han F. Vermeulen, "The German Invention of Völkerkunde: Ethnological Discourse in Europe and Asia, 1740-1798," in The German Invention of Race, ed. Sara Eigen and Mark Larrimore (Albany: State University of New York Press, 2006), $123-45$, here 132 .

10 Ratio educationis totiusque rei litterariae per Regnum Hungariae [Program for education in all literary fields throughout the Kingdom of Hungary] (Vienna: Trattern, 1777), 4.

11 Milan Zafirovski, The Enlightenment and Its Effects on Modern Society (New York: Springer, 2011), 181.

12 Evans, Austria, Hungary, and the Habsburgs, 48. 
an editor of one of Pray's lesser-known works, ${ }^{13}$ and the first director of the National Museum in Budapest, studied universal history and bibliography with Kollár. Notably, Miller had studied law in Trnava, a field in which the Jesuits there were not engaged. Decades after the suppression, Miller published a work that explicitly referenced patriotism, a concept that would never have been part of Jesuit training. ${ }^{14} \mathrm{He}$ also published a work on the Hercules cult practiced in Roman times in what was later Banat; this study resembles scholarship in which Jesuits had long engaged even if it was not the exclusive preserve of the Society. ${ }^{15}$ The latter work is likewise at the very least comparable to the publications undertaken by Kollár and others in the Enlightenment "Republic of Letters." Miller's case raises the question of whether an identifiable "Jesuit heritage" among the activities of former Jesuits of the Habsburg lands and their protégés did in fact exist. ${ }^{16}$ In addition to his theoretical writings, Kollár undertook pathbreaking archival work. Kollár devoted considerable time to the meticulous copying of manuscripts, an activity that gave him an intimate familiarity with the paleography and Latin style of these documents. ${ }^{17}$ Kollár's publication of a history by Caspar Ursinus Velius (c.1493-1539), the court historian of Ferdinand I (r.1558-64), was based on manuscripts in the Imperial Library in Vienna. ${ }^{18}$ Almost simultaneously Kollár published a collection of documents from Viennese archives dealing with the reign of Friedrich III (r.1452-93) ${ }^{19}$ Kollár's court connections enabled him to publish these volumes without delay, and with the prospect of a wide and distinguished audience. The Latin and Greek poem Kollár wrote in praise of Maria Theresa and

13 Gabrielis Bethlenii principatus Transilvaniae coaevis documentis illustratus... [The Principality of Transylvania in the time of Gabriel Bethlen, illustrated with contemporaneous documents] (Pest: Joannis Thomae Trattner, 1816).

14 Jac. Ferdin. von Miller, Versuch patriotischer Vorschläge zur Aufnahme der ungarischen Sprache [An attempt at patriotic suggestions for the adoption of the Hungarian language) (Pest: bey Joseph Eggenberger, 1806).

15 Hercules Mehadiensis animadversionibus criticis illustratus [The Hercules (cult) of Mehadia, with a critical commentary] (Pest: Apud Iosephum Eggenberger, 1806).

16 Paul Shore, "Ex-Jesuits in the East Habsburg Lands, Silesia, and Poland," in The Jesuit Suppression: Causes, Events and Consequences, ed. Jeffrey D. Burson and Jonathan Wright (Cambridge: Cambridge University Press, 2015), 246-47.

17 Reinhold Münster, "Enlightenment Perspectives on the Middle Ages" Handbook of Medieval Studies: Terms - Methods - Trends, ed. Albrecht Classen, 3 vols. (Berlin: Walter de Gruyter, 2010), 1:479.

18 Casparis Ursini Velii De bello Pannonico libri decem [Ten books on the Hungarian war, by Caspar Ursinus Velius] (Vienna: Typis Joannis Thomae Trattner, 1762).

19 Analecta monumentorum omnis aevi Vindobonensia [Records of Vienna from every historical period], 2 vols. (Vienna: Joannis Thomae Trattner, 1761-62). 
her consort Francis captures some of this relationship, while preserving more than a hint of the older, baroque style that Jesuits had long used in their dealings with monarchs. ${ }^{20}$ Kollár called himself "Pannonius," ${ }^{21}$ a (strictly speaking, inaccurate) geographic, rather than ethnic or linguistic designation, but he consistently identified with his Slavic roots while exhibiting a loyalty to Hungary as a realm. ${ }^{22}$ By identifying with the kingdom, not its ethnic Hungarian aristocracy Kollár positioned himself to support the claims of the Habsburg dynasty, a foreign entity whose authority in Hungary had been challenged only sixty years earlier, and whose claims to supremacy were rooted in an ancient sacral arrangement which the Roman term "Pannonius" called to mind. In 1764, Kollár published a treatise stressing the rights of the crown, and thus by implication the Habsburgs. ${ }^{23}$ The public statement of this position placed him in opposition to the Hungarian "Nation" (meaning, in the eighteenth century, the Magyar nobility and the high clergy of the Hungarian Catholic Church). ${ }^{24}$ Although Kollár's book was a carefully argued work of historical scholarship, it was placed on Rome's Index librorum prohibitorum and ultimately had to be withdrawn. ${ }^{25}$ A consequence of this setback was the failure of Kollár's scheme

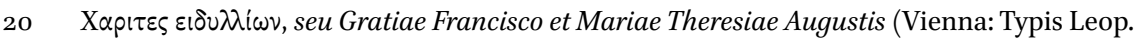
Joan. Kaliwoda, 1765). Kaliwoda (Kalivoda) was printer to the imperial court.

21 Joachim Bahlcke, Ungarischer Episkopat und österreichische Monarchie: Von einer Partnerschaft zur Konfrontation (1686-179o) [Hungarian episcopacy and Austrian monarchy: from a partnership to confrontation (1686-1790)] (Stuttgart: Franz Steiner, 2005), 267.

22 In a 1749 treatise on the history of the Rusyn, Humillium promemoria de ortu, progressu et in Hungaria incolatu gentis Ruthenicae [A most humbly submitted promemoria on the origin, progress, and settlement in Hungary of the Ruthenian people]. Kollár applied his skills to the defense of a Slavic population which had received scant attention from the wider Catholic world. Paul Robert Magocsi, With Their Backs to the Mountains: A History of Carpathian Rus' and Carpatho-Rusyns (Budapest: Central European University Press, 2015), 103.

23 Adami Francisci Kollarii [...] De originibus et usu perpetuo potestatis legislatoriae circa sacra regum Hungariae libellus singularis [An individual petition concerning the origins and perpetual use of legislative power regarding the holy privileges of the kings of Hungary [...] by Adam Francis Kollár] (Vienna: Typis Joannis Thomae de Trattner, 1764).

24 Franz A. J. Szabo, Kaunitz and Enlightened Absolutism 1753-1780 (Cambridge: Cambridge University Press, 1994), 324-25.

25 László Kontler, “Distances Celestial and Terrestrial: Maximilian Hell's Arctic Expedition of 1768-1769: Contexts and Responses," in Scholars in Action: The Practice of Knowledge and the Figure of the Savant in the $18^{\text {th }}$ Century, ed. André Holenstein, Hubert Steinke, and Martin Stuber (Leiden: Brill, 2013), 2:721-5o, here 745, doi: 10.1163/9789004243910_032 (accessed January 19, 2019)The list of suspect authors (Pufendorf, Thomasius, Hobbes) upon 
to establish a Hungarian learned society to gain any traction. ${ }^{26}$ Yet this debacle does not appear to have cost him his influence at court, or damaged his ability to continue to publish widely influential books. On the other hand, Kollár's centralist views, which are now seen as endorsements of enlightened absolutism, and his interpretations of Hungarian history, continued to produce negative reactions in ex-Jesuit circles after his death. ${ }^{27}$ Kollár's career suggests that he was far more comfortable setting forth innovative projects and placing himself in settings where his personal ambitions might be realized than was Pray. ${ }^{28}$ Kollár's long years spent in the Habsburg capital in very prominent posts is likely a consequence of these ambitions. Whatever the causes, the outcome of Kollár's efforts was a very high level of engagement with Enlightenment ideas. Kollár's interests were truly extensive and eclectic, extending to the history of law. ${ }^{29} \mathrm{He}$ also studied the history of the Turkish language (having rediscovered a set of seventeenth-century Turkish typefaces, he edited a volume on the study of Turkish). ${ }^{30}$ Beyond Kollár's legal and historical interests, he has

whose ideas Kollár was accused of basing his arguments reveals much about the anxieties of traditionalists in Theresian Hungary.

26 Letter from Kollár to Samuel Dobai Székely, Vienna, February 4, 1763, in Learned Societies, Freemasonry, Sciences and Literature in 18th-Century Hungary: A Collection of Documents and Sources, ed. Gábor Tüskés and Réka Lengyel (Budapest: MTA Bölcsészettudományi Kutatóközpont Irodalomtudományi Intézet, 2017), 38. Kollár's idea was to create a body without confessional or ethnic restrictions; he had earlier proposed the creation of a German scientific society in Vienna. See István Soós, "Die Korrespondenz von Adam Franz Kollár" [The correspondence of Adam Francis Kollár], in Nation und Nationalismus in wissenschaftlichen Standardwerken Österreich-Ungarns ca. 1867-1918 [Nation and nationalism in scientific reference works of Austria-Hungary, c. 1867-1918], ed. Endre Kiss, Csaba Kiss, and Justin Stagl (Vienna: Böhlau, 1997), 15-32, here 21.

27 See for example, Ignatius Bärenkopf, De dominio nobilium Hungariae deque cladis ad Mohacsum causa... [Concerning the commonwealth of the nobility of Hungary and the cause of the defeat at Mohács] (Bratislava: Sumptibus et Typis S. P. Weber, 179o). See also Johann Nepomuk Stoeger, Scriptores Provinciae Austriacae Societatis Jesu (Vienna: Typis Congregationis Mechitharisticae, 1855), 18-19.

28 Like all Jesuits of his day, Kollár was initially trained in a facultas linguarum where language skills were the foundation of more advanced academic studies. Jan Tibenský, Slovenský Sokrates: Život a dielo Adama Františka Kollára [Slovak Socrates: the life and work of Adam František Kollár] (Bratislava: Tatran, 1983), 14.

29 Berlász Jenő, “Az Illésházy-könyvtár: Fejezet az Országos Széchényi Könyvtár állomány történetéből" [The Illésházy library: a chapter from the history of the founding of the National Széchényi Library], Az Országos Széchényi Könyvtár Évkönyve [Yearbook of the National Széchényi Library] (1967): 57-97, here 76.

$30 \quad$ Francisci à Mesgnien Institutiones linguae turcicae cum rudimentis parallelis linguarum arabicae et persicae [...] aucta: Curante Adamo Francisco Kollar; Editio altera [Foundations 
also been linked with a Viennese newspaper, Die K. k. allergnädigst privilegierten Anzeigen, which appeared between 1771 and $17766^{31}$ In a somewhat different vein Kollár published late medieval conciliarist documents, a project generally compatible with the Habsburg court's efforts to restrict the power of Rome and of interest to reformers within the Catholic Church. ${ }^{32}$ As Ulrich L. Lehner points out, the prince-bishops of the Empire felt the need to defend their autonomy against papal nuncios, and so were supporters of Kollár's work on these documents. ${ }^{33}$ The contrast with Jesuit support of the pope, to whom every Jesuit vowed obedience, is striking. Kollár may have been motivated by the desire to cultivate potential patrons from the highest ranks of the Empire's elites, but his genuine desire to bring these important documents to light was an equally likely reason for his program. In any case, the historical scholarship of Kollár, the former Jesuit, stands far apart from that of his colleagues. These tasks carried Kollár's work beyond source collecting and collating and injected his historical research into the heart of political controversies over Enlightenment absolutism in the Habsburg lands, thereby earning him an enduring international reputation.

\section{$2 \quad$ György Pray}

Georgius (György) Pray was born in Nové Zámky (German: Neuhäus[el], Hungarian: Érsekújvár) in 1723 , to a family of noble south Tyrolean origin with

of the Turkish language, including parallels with the Arabic and Persian languages, by Franciscus Mesgnien, revised by Adam Franciscus Kollar, second edition], 2 vols. (Vienna: Ex Typographo Orientali Schilgiano, 1756). This press was connected with the well-known publishing firm of Johann Baptist Schilgen (1687-1743). Anton Mayer, Wiens BuchdruckerGeschichte, 1482-1882 [The history of Vienna's book printers, 1482-1882], 2 vols. (Vienna: W. Frick, 1883-87), 2:18. See also Paula Sutter Fichtner, Terror and Toleration: The Habsburg Empire Confronts Islam, 1526-1850 (London: Reaktion Books, 2008), 121.

31 Andrea Seidler and W Seidler, "Das deutsche Zeitschriftenwesen des Donauraumes (Wien— Pressburg—Pest—Buda) in der zweiten Hälfte des 18. Jahrhunderts” [German newspaper publication in the Danube Region (Vienna—Bratislava-Pest—Buda) during the second half of the eighteenth century"), in A magyar nyelvés kultúra a Duna völgyében [The Hungarian language and culture in the Danube valley], ed. Csáky Moritz et al. (Budapest: Nemzetközi Magyar Filológiai Társaság, 1989), 106-14, here 109.

32 Ulrich L. Lehner, On the Road to Vatican II: German Catholic Enlightenment and Reform of the Church (Minneapolis: Fortress Press, 2016), 147.

33 Ulrich L. Lehner, "Johann Nikolaus von Hontheim's Febronius: A Censored Bishop and His Ecclesiology," Church History and Religious Culture 88, no. 2 (2008): 205-33, here 209. 
connections to the imperial officer corps. ${ }^{34}$ After entering the Society at the age of seventeen, he studied in Vienna before serving in Győr, Trnava, and Buda, as well as teaching at the Theresianum in Vienna. In each of these appointments Pray taught a variety of subjects, a typical range of employment for even highly specialized Jesuit scholars in eighteenth-century Hungary. By the time of the suppression, Pray - who was indebted in his methodology to the French scholar Joseph de Guignes (1721-180o), and had studied with Hungarian Jesuit historian Nicolaus Schmitth (1707-67) — had already published major collections of original documents related to Hungarian history, the most important of which was a five-volume survey of the medieval kings of Hungary. ${ }^{35}$

The year 1773 marked a milestone in book culture throughout the Habsburg lands: the stocks of Jesuit presses were dispersed, to be sold by private book dealers, ${ }^{36}$ and Jesuits like Pray who were experts in philology, diplomatics, and archival research were compelled to find new appointments. Pray fared much better than most. After a stint as a librarian in Bratislava, in 1777 he was appointed official Historiographer of Hungary (Historiographus Hungariae) by Maria Theresia, an acknowledgement, not only of Pray's scholarly gifts, but also of his growing body of writings on the history of Hungary. ${ }^{37}$ Pray's new

34 Antall József, “A Pray család magyarországi történetének összefoglaló ismertetése” [Summary of the Hungarian history of the Pray family], Jászsági Évkönyv [Jászság Yearbook] 13 (2005): 41-48, here 45 .

35 Annales regvm Hvngariae ab anno Christi CMXCVII ad annvm MDLXIV [Annals of the kings of Hungary from A.D. 997 to 1554 [...] by Georgius Pray], 5 vols. (Vienna: Sumptibus Augustini Bernardi, Bibliopolae Universitatis, 1764-70). For Pray's indebtedness to Joseph de Guignes, see Szabados György, “Jezsuita 'sikertörténet' (1644-1811): A magyar történettudomány konzervatív megteremtőiről” [Jesuit history of success (1644-1811): conservative creators of Hungarian historiography"], in Clio inter arma: Tanulmányok a 16-18. századi magyaroszági történetírásról [Clio at war: studies in Hungarian historical literature of the sixteenth through eighteenth centuries], ed. Tóth Gergely (Budapest: MTA Bölcsészettudományi Kutatóközpont Történettudományi Intézet, 2014), 206-26, here 212; for his association as the pupil of Nicolaus (Miklós) Schmitth, see Hóman Bálint, A forráskutatás és forráskritika története [The history of source research and source criticism] (Budapest: Kiadja a Magyar történelmi társulat, 1925), 21, http://mek.niif.hu/o710o/o7139/ html/ooog/oo11-352.html (accessed January 19, 2019). See also Lóránt Czigány, The Oxford History of Hungarian Literature (Oxford: Clarendon Press, 1984), 66.

36 Victor Segesvary, The History of a Private Library in 18th Century Hungary: The Library of Pál and Gedeon Ráday, trans. Edith Enikő Jókay (The Hague: Mikes International, 2005), 153n5, http://www.federatio.org/mi_bibl/VictorSegesvary_Raday.pdf (accessed November 21, 2018).

37 Harald Zimmermann, Der Deutsche Orden in Siebenbürgen: eine diplomatische Untersuchung [The German order in Transylvania: an investigation of documents] (Köln: Böhlau, 
position was created at the point when the Jesuit-founded University of Trnava, and its library were being moved to Buda. This transfer was a geographical and symbolic re-centering of Hungarian academic culture, relocating the university in the middle of the Hungarian plain and in the city that had been the seat of the flourishing Renaissance court of Matthias Corvinus (r.1458-90). The move also came at a point when the Turkish threat had long ago receded and the need to identify Hungarian culture as specifically Christian and Catholic as opposed to Muslim and alien had correspondingly decreased.

Pray now produced a register of rare books in the university collection which demonstrated his familiarity with the value and significance of the collection's early printed materials, many of which had been gathered not merely from Hungary, but from a wider European ambit. ${ }^{38}$ Pray resigned from this post in 1780 only to return in 1782 . In 1784 , the university moved again, this time to Pest, at which point Pray requested that the Hevenesi document collections (originally consisting of 140 volumes, which the Jesuit historian Stephanus Kaprinai [1714-85] had expanded to 323 volumes) be moved to the University Library, a process that was only completed in $1790 .{ }^{39}$ Pray contributed his own collection of manuscripts to the library, and was also engaged in heraldry and sigillography, taking over the curation of collections of these objects from Carolus Wagner (1732-90), another former Jesuit who had been a custos of the library. ${ }^{40}$

Less clear is Pray's relationship to incipient Hungarian nationalism, as defined by his interest in the vernacular language (as likewise supported in Kollár's Ratio educationis), and what would come to be called so-called traditional Hungarian "folkways." Like his predecessors Hevenesi and Kaprinai, Pray had a keen interest in the history of the medieval Kingdom of Hungary, to which he

2011), 18. Pray was also appointed Typographiae praefectus at the university, according to Stoeger, Scriptores, 277.

38 Pray's commentaries are occasionally entertaining, as when he describes an introduction by Leibnitz as "erudite non minus quam prolixe." Index rariorum librorum Bibliothecae Universitatis Regiae Budensis [Index of the rare books in the Library of the Royal University in Buda], 2 vols. (Buda: Typis Regiae Vniversitatis, 1780-81), 2:31.

39 Tóth Ferenc, "La naissance de l'historiographie moderne en Hongrie à l'époque des Lumières" [The birth of modern historiography in Hungary in the age of Enlightenment], in Les historiographes en Europe de la fin du moyen âge à la révolution [The historiographers of Hungary from the end of the Middle Ages to the revolution], ed. Chantal Grell (Paris: Presses de l'Université Paris-Sorbonne, 2006), 187-202, here 196.

40 Csaplár Benedek, Révai Miklós élete [The life of Miklós Révai] vol. 1 (Budapest: Aigner Lajos, 1881), 73; Johann Matthias Korabinsky, Geographisch-historisches und Produkten: Lexikon von Ungarn [Geographical and historical product: lexicon of Hungary] (Bratislava: Weber und Korabinsky, 1786), 496. 
added his own explorations of the place of the "fatherlands and ancient seats" of peoples. ${ }^{41}$ Moreover, just as Kollár had advanced Habsburg claims for more centralized imperial state governance over Hungary, Pray similarly defended the right of the Kingdom of Hungary to rule over Dalmatia. But Pray could also write about Catholic saints and their virtues in a way reminiscent of high baroque panegyric, a trait he shared with contemporaneous Hungarian Jesuits such as Joannes Frivaldszky (1730-84). ${ }^{42}$

Had he done nothing else, Pray, who has been described as "without a doubt the greatest historian of eighteenth-century Hungary,"43 would still been remembered for his identification of the Codex Pray (Országos Széchényi Könyvtár MNy 1), which includes the Halotti beszéd és könyörgés (Funeral oration and prayer) dating to about 1199 and the oldest surviving continuous Hungarian (and Uraltic) text. The entire text was published in 1770 and generated considerable excitement. ${ }^{44}$ Its appearance coincided with a growing interest among Hungarians in their Magyar origins, and in the early history of the Hungarian

41 Pray corresponded regarding these questions with the Jesuit astronomer Maximilian Hell (1720-94), an indication of the degree to which Hungarian Jesuits were engaged with the questions of origins and relations to other Asian populations. László Kontler, "The Uses of Knowledge and the Symbolic Map of the Enlightened Monarchy of the Habsburgs: Maximilian Hell as Imperial and Royal Astronomer," in Negotiating Knowledge in Early Modern Empires: A Decentered View, ed. László Kontler, Antonello Romano, Silvia Sebastiani, and Borbála Török (New York: Palgrave, 2014), 98. Indeed, the significance of not just the Hungarian Jesuits, but also French Jesuits in the study of Asian cultures is treated in this issue. See Carolina Armenteros, "The Enlightened Conservatism of the Malabar Missions: Gaston-Laurent Coeurdoux (1691-1779) and the Making of an Anthropological Classic," JJs 6, no. 3 (2019): 439-66.

42 Writing about the sainted (if not particularly saintly) first king of Hungary, Stephen, Pray asserted, "Divina virtus in vita sua demonstrare voluit" [he desired to demonstrate divine virtue in his life], in Dissertatio historico-critica de sacra dextera Divi Stephani primi Hungariae regis [Historical-critical dissertation on the sacred right hand of St. Stephen, first king of Hungary] (Vienna: Joannis Thomae Trattnern, 1771), 148.

43 François Cadilhon, "De la Bibliothèque du roi au Collège de France: Recherches sur les origines hongroises au XVIII ${ }^{\mathrm{e}}$ siècle" [From the King's Library to the Collège de France: research on the origins of the Hungarians in the eighteenth century] Revue français de l'histoire du livre, new series, 126-27 (2005-6): 149-58, here 157.

44 Sajnovics János, Demonstratio idioma Ungarorum et Lapponum idem esse, ed. Szíj Enikő (Budapest: ELTE, 1994), 23-25. Sajnovics (1733-85) was a Jesuit linguist and explorer. Faludi Ferenc (1704-79), another Jesuit, provided the first rendering of this text into modern Hungarian. Danilo Gheno, “A Halotti beszéd és az Ómagyar Mária-siralom: Gondolatok és javaslatok" [The funeral oration and the old Hungarian mourning of Mary: thoughts and suggestions"], Magyar Nyelvör [Hungarian language sentinel] 132, no. 3 (2008): 341-48, here 343 . 
language - a process that engaged with Enlightenment philosophy of history. ${ }^{45}$ The desire to locate Hungarian history within an existing European narrative was accompanied by a persistent curiosity regarding the Asiatic origins of the Magyars, and the archival work of an earlier Jesuit, Martinus Cseles (1631-1709), had fostered these interests. Indeed, another Jesuit librarian, Stephanus Kaprinai, had been the one to conserve these manuscripts of Cseles. ${ }^{46}$ Pray also published a five volume study of Hungarian kings to 1564 , but did not gain access to some of the most important archival sources in Vienna from the seventeenth century, because the Habsburg court would only have allowed the production of Pray's history if it had cast the dynasty in the best possible light, something Pray apparently refused to do.

Pray appears to have been deeply conscious of his Hungarian heritage, and so revealed his interest in specifically Hungarian history in his researches and discoveries. In this regard he differed from the "Pannonius" Kollár, whose interests and contacts with Enlightenment figures led him to attempt definitions of ethnic groups rather than to focus on one group exclusively. Pray's work therefore might seen as contributing less explicitly to an Enlightenment agenda, but the quality of his research and the careful documentation that accompanied his publications added to the critical quality of Hungarian historiography, thereby inevitably drawing future Hungarian scholars ever closer to the Enlightenment.

To these complications was added the problem of how Jesuit and former Jesuit historians should interpret more recent events in which the Society itself had played a role. In the eastern Habsburg lands this issue was particularly acute since Jesuit efforts to develop a Uniate Church in Transylvania had stirred up anti-Catholic sentiments among Orthodox ethnic Romanians, and enduring memories of the Society's aggressive opposition to Calvinism endured. And the awkward fact that some Jesuits in Transylvania had supported the abortive rebellion of Rákóczi remained. Pray and Kollár worked as individuals within this complex and at times opaque setting, but they remained in touch with Enlightenment thought concerning historical writing. Pray's

45 László Kontler, "The Lappon, the Scythian and the Hungarian, or Our (Former) Selves as 'Others': Philosophical History in Eighteenth-Century Hungary," in Encountering Otherness: Diversities and Transcultural Experiences in Early Modern European Culture, ed. Guido Abbattista (Trieste: Edizioni Universitá di Trieste, 2011), 131-45.

46 Paul Shore, "Martinus Cseles, SJ, Brother Julianus, and the Rediscovery of Magna Hungaria," in A Divided Hungary in Europe: Exchanges, Networks, and Representations, 1541-1699, vol. 1: Study Tours and Intellectual-Religious Relationships, ed. Gábor Almási (Newcastle upon Tyne: Cambridge Scholars Publishing, 2014), 183-99, here 185. 
output was also shaped by the demand for textbooks in a post-179o Hungary now dotted with village schools. In 1801, he produced a three-volume Latin history of Hungary intended for upper elementary school students that presented a heavily pro-Habsburg account of events at a point when the dynasty was under severe pressure from Napoleonic expansion. ${ }^{47}$ Hungarian national identity and Habsburg dynastic credibility were thus joined once more in the presentation of national history as they had been during the time of Jesuit historian Melchior Inchofer (c.1584-1648). ${ }^{48}$

Both Kollár and Pray worked in large, urban libraries, whose role was evolving rapidly in the late eighteenth century. Previously the preserve of religious orders, private individuals, and a few learned and scientific societies, libraries grew quickly to become part of the public culture of European cities during the eighteenth century. Libraries also became focal points of national identity and language. The National Library of Hungary, founded a year after Pray's death, was the result of efforts by Count Ferenc Széchényi (1754-1820) to acquire Hungarian language books and grew to be an object of national pride. Because significant portions of the literary community of Hungary had, despite Jesuit efforts, always remained non-Catholic, the evolution of library culture towards a more secularized or at least multi-confessional orientation did not constitute a profound disruption. The willingness of both Kollár and Pray to draw on non-Catholic sources in their own work paved the way for these developments. Kollár's and Pray's interest in the "ancient seats" of populations also prefigured debates regarding the "original" inhabitants of such regions as Transylvania where Hungarians and Romanians would both claim to have settled the land first.

Kollár and Pray was also products of late baroque Jesuit book and library culture, which was highly developed in eighteenth-century Habsburg Hungary. Notably, both men came from "upper Hungary" where the Jesuits had a wellestablished network of communities and schools. In addition to the library at Trnava university, significant collections existed in the Jesuit communities of

47 Historia Regum Hungariae [...] opera et studio Georgii Pray... [History of the kings of Hungary (...), by Georgius Pray...], 3 vols. (Buda: Regiae universitatis Pestanae typographia, 1801).

48 Paul Shore, Narratives of Adversity: Jesuits on the Eastern Peripheries of the Habsburg Realms (1640-1773) (Budapest: Central European University Press, 2012), 212-13. 
Košice, Bratislava, Sárospatak, Turčiansky Svätý Martin, and Uzhhorod whose schools formed an arc reaching eastward along the Carpathians. ${ }^{49}$ While these collections privileged religious subjects, other disciplines such as medicine, mathematics, and history were also represented, often including ideas (sometimes rephrased or uncredited) that were generated by writers in the wider European "Republic of Letters." Jesuits proceeded with caution here for two reasons: first, the continual involvement of the Society in Hungary with a more traditional, pre-scientific piety; and second, because the church they served was increasingly in conflict with Enlightenment thinkers. Jesuit publishing and educational projects had never completely abandoned the vernacular, and they thereby maintained a connection with a wider public. When the Trnava university relocated to Pest eleven years after the suppression, instruction in the vernacular had already begun. Nevertheless, the library culture of Habsburg Hungary during the years of suppression was also affected by the confiscation and relocation of collections resulting from Joseph II's reforms. For example, most of the Jesuit collection in Bratislava, where had Pray taught, was transferred to the Buda University in the $1780 .^{50}$ Books from Jesuit collections also filled gaps in the Court Library in Vienna. ${ }^{51}$ As the culmination of a more subtle and long-term process that had commenced decades earlier, the motivation for the collection of library materials shifted away from confessional competition and towards the assembling of materials from a wide range of disciplines for the training of professionals and bureaucrats-a process that served both Vienna's ambitions and the dreams of nationalists. The promotion of a more secular concept of virtue as expressed by Enlightenment thinkers and set forth in the Ratio educationis, likewise hastened the appearance of the "Athleta nationis" which supplanted (but sometimes paralleled) the baroque ideal of the "Athleta Christi." ${ }^{22}$ The Athleta Christi, a term deriving from the history of the early church, was applied in the era of struggle with the Ottomans to soldier princes such as John Hunyadi $(1406-56)$ or Nicolaus Zrínyi (1620-64) who were held up as models of noble self-sacrifice and defence of

49 Farkas Gábor et al., Magyarországi jezsuita könyvtárak 1711-ig [Hungarian Jesuit libraries, to 1711], vol. 1: Kassa, Pozsony, Sárospatak, Turóc, Ungvár (Szeged: Scriptum, 1990). The Košice library alone held more than four thousand volumes.

50 Gábor et al., Magyarországi, xiv.

$5^{1} \quad$ Von Mosel, Geschichte, 164.

52 László Szikay, "Les genres en vers dans les littératures des langues européennes entre les Lumières et le Romantisme" [Verse genres in the literatures of European languages between the Enlightenment and Romanticism], trans. Mireille Tóth, in Le Tournant du siècle des lumières, 1760-1820, ed. György Mihály Vajda (Amsterdam: John Benjamins, 2009), 213-85, here 215 . 
Christendom..$^{53}$ By contrast, the "Athleta nationis" had no connection to either the antique notion of heroism or to the idea of Christians defending the faith against its enemies. In fact, in the era of Ossian the ideal of the "Athleta nationis" possessed elements of the romantic, as national epics and myths were reworked to emphasize national heroes, some of whom might be pagan. ${ }^{54}$ The worldly goals of these latter athletae were easily adapted for the educational programs of countries seeking to develop as enlightened monarchies.

Beyond the obvious fact of Kollár's departure from the Society, other differences are apparent in the careers of these two men. Pray spent time in Vienna on more than one occasion, but the bulk of his life as a Jesuit and ex-Jesuit was passed far from the Habsburg capital. The Society's records show that Hungarian was Pray's native tongue and Slovak Kollár's, and although the latter especially possessed a great facility for languages, this difference, and the differing senses of identification following from it, surely helped shape the choice of tasks each undertook and the ways these tasks were pursued. Kollár's Hebrew training, which occurred in the stimulating environment of Vienna, opened a door to his engagement with other non-European languages. Kollár was in intimate contact with the Habsburg court for decades where he had cultivated friendships with such luminaries as van Swieten, an experience unknown to Pray.

Subsequent events carried the contributions of these men in directions they may not have anticipated. The French Revolution and Napoleonic wars further disrupted communication and distribution of printed works, even as declining university enrollments were still another factor contributing to this disruption, as well as a pronounced symptom of the same. The tensions between the universalism espoused in different ways by both baroque culture and the Enlightenment, on the one hand, and by emerging nationalism, on the other, only intensified in the nineteenth century. The legacy of these former Jesuits was utilized by Hungarian, Romanian, and Slovak scholars whose nationalist goals were increasingly estranged from the universalist ideals of the Enlightenment. Kollár has been claimed as a Hungarian by Hungarians and a Slovak by

53 Bene Sándor, Theatrum politicum (Debrecen: Kossuth Egyetemi Kiadó, 1999), 79; Hanna Orsolya Vincze, The Politics of Translation and Transmission: Basilikon doron in Hungarian Political Thought (Newcastle upon Tyne: Cambridge Scholars Press, 2012), 186. The Jesuit collegium in Trenčin produced a play about John Hunyadi in 1723 while the Trnava university presented a drama on Zrínyi as late as 1753 . Staud Géza, A magyarországi jezsuita iskolai színjátékokforrásai [The sources of Hungarian Jesuit school dramas], 3 vols. (Budapest: A Magyar Tudományos Akadémia Könyvtárának Kiadása, 1984-88), 2:280 and 1:203.

54 Bojtár Endre, Hazát és népet álmodánk [...] [We had a dream about our country and people] (Budapest: Typotex, 2008), 134-35. 
Slovaks. His championing of the identity of the Rusyn seems to place him in the pro-Slavic camp, but his use of the Habsburg possession of the "apostolic" crown of Hungary draws on a simultaneously national and transnational sense of identity that has been exploited by Hungarian nationalists to this day. Pray's observation on the origins of the Csángós have been used to propose a model of their relations to other ethnic groups in the region. ${ }^{55}$

Kollár's and Pray's contributions stand among those of other distinguished former Jesuits: Stephanus Katona (1732-1811) built on (and sometimes corrected) Pray's work, producing a monumental series on Hungarian history running to dozens of volumes. ${ }^{56}$ Stephanus Schönwiesner (1738-1815 or 1818), who acquired Pray's manuscripts after his death, produced a history of Szombathely. ${ }^{57}$ Josephus Koller $\left(1745^{-18} 3^{2}\right)$ published a history of Pécs. ${ }^{58}$ Kollár, who left the Society early and voluntarily, seems especially to have gone his own way. What these men and their colleagues had in common, however, was a formation that stressed careful observation and record keeping, valued the written word, and that understood the importance of libraries to the building of a literate community. Jesuit institutional culture also laid stress on a systematic and documented approach to language study, whether the language in question was classical and familiar, or newly known to Europeans, and on the essential value of the written and spoken word to communicate universal truths. More broadly the Jesuit worldview saw the increase in knowledge as good, something with which Enlightenment thinkers agreed. Yet whether Kollár and Pray continued as researchers to draw on the religious underpinnings of their Jesuit formation is harder to determine.

Despite the Society's condemnation of personal ambition, we can view the accomplishments of both men as the result of a desire to excel, albeit expressed in different ways. Pray lived into the era following the Jacobin conspiracies of

55 Gökhan Dilbaş, “Csángóllarin Kökeni Üzerine” [On the origins of the Csángós], Balkan Araştırma Enstitüsü Dergisi: Trakya Üniversitesi [Journal of Balkan Research Institute: Trakya University] 3, no. 2 (December 2014): 17-44, here 28, http://dergipark.gov.tr/download/article-file/407941 (accessed November, 21, 2018).

$5^{6} \quad$ Historia critica regum Hungariae ex fide domesticorum et exterorum scriptorum concinnata a Stephano Katona [A critical history of the kings of Hungary, based upon domestic and foreign documents, compiled by Stephanus Katona], 42 vols. (Pest:Sumptibus I. M. Weingand, etc., 1779-1817).

57 Antiquitatum et historiae Sabariensis ab origine usque ad praesens tempus libri IX cum iconibus [Ten books of the antiquities and history of Szombathely from its origins to the present day] (Pest: M. Trattner, 1791).

$5^{8}$ Historia episcopatus quinque ecclesiarum [History of the episcopate of Pécs], 8 vols. (Bratislava: Typis Joannis Michaelis Landerer de Füskút, 1784-1812). 
1792-96, which saw severe restrictions placed on scholarly inquiry and expression, and he sometimes responded accordingly. Kollár's career ended just as the reforms of the Habsburg monarchs were gaining momentum and expectations for the advancement of scholarship and education were rising-for a while this wave seemed to have no end in sight and Kollár took the chances that such a viewpoint fostered. Nevertheless, Kollár and Pray shared important commonalities from their years in the Society. Besides training in languages, the program of the Ratio encouraged a tendency to turn to history not merely for moral instruction, but also for clues as to the origins of later conditions, a principle that Kollár applied in his definition of ethnologia. Pray's search for origins of the Magyars led him not towards theoretical innovations, but to the searching and sifting of documents, aided by philological principles, that resulted in his identification of the Codex Pray and the compilation of a register of rare books. Neither man, however can be called a typical ex-Jesuit or even a typical ex-Jesuit scholar of the Habsburg realms, as most were less obviously "literary" figures and tended to live more obscure and tenuous existences, often in small communities. Ultimately, the limited career paths open to young men with the talents and interests of Kollár and Pray had much to do with how they came to be Jesuits, something that these two scholars share with many Jesuits worldwide who survived into the tumultuous post-Suppression era.

4

Conclusion

Hungarian Jesuit scholars active in 1773 were heirs to diverse and at times competing legacies. Awareness of, and pride in Hungarian language and history had never died out among the Catholic clergy, and the excitement generated by the discovery and publication of documents such as the Halotti beszéd represented less of a break with the past than a reawakening of a sense of connection with a remembered national narrative. But the relationship among the hierarchy of the Catholic Church, the Viennese court, persistently Calvinist elements of the aristocracy, an emerging bourgeois reading public, and the network of Jesuits and former Jesuits was often unharmonious. By the 1760 s, Jesuits faced serious opposition both within and beyond the Habsburg lands, and challenges to the supreme position of the Catholic Church in many Austrian political contexts was increasing. The disappearance of the existential threat of Ottoman forays into Central Europe diluted the argument that the House of Habsburg and the church should have identical aims, while centralists such as Kollár now advocated the supremacy of the dynasty using arguments that no longer referred to the defense of Christian Europe from its enemies. The French Revolution, 
the demise of the Holy Roman Empire, and the creation of a new and purely dynastic Austrian one lay only a few decades ahead, and just beyond would come the resurrection of a new Society of Jesus, one with different aims and methods than the one that had trained Pray and Kollár.

\section{Acknowledgement}

Thanks to the Principal of Pusey House Oxford, George Westhaver, who provided a stimulating setting in which to complete this work. Lynn Whidden and Béla Vilmos Mihalik provided editorial advice and assistance regarding details of Hungarian Jesuit history, respectively. In what follows, the Hungarian language convention of listing the surname of authors and editors before the given name has been followed in the notes, and for works published before the first quarter of the nineteenth century, Buda and Pest have been listed as separate cities in order to avoid anachronism. 